\title{
STUDI CASE CONTROL: KEBIASAAN MAKAN DAN HUBUNGANNYA DENGAN KEJADIAN STUNTING PADA ANAK BALITA DI DESA PADENDE KECAMATAN MARAWOLA
}

\author{
${ }^{1}$ Hepti Muliyati, ${ }^{2}$ Tuty Hertati Purba, ${ }^{1}$ Hasnidar, ${ }^{1}$ Nur Rahmi \\ ${ }^{1}$ STIKes Widya Nusantara Palu, ${ }^{2}$ Institut Kesehatan Helvetia, \\ heptimuliyati@stikeswnpalu.ac.id
}

\begin{abstract}
Abstrak
Stunting merupakan akibat kekurangan gizi kronis yang mulai terlihat setelah anak berusia dua tahun. World Health Organization melaporkan bahwa prevalensi stunting di dunia sebesar 22,9\%. Balita dengan masalah stunting di Desa Padende dari tahun 2017 sampai 2019 sebanyak 33 anak. Tujuan penelitian ini yaitu menganalisis kebiasaan makan dan hubungannya dengan kejadian stunting pada anak balita di Desa Padende Kecamatan Marawola. Jenis penelitian ini adalah penelitian kuantitatif dengan menggunakan rancangan case control. Populasi dalam penelitian ini adalah semua balita di Desa Padende Kecamatan Marawola pada tahun 2019 sebanyak 139 balita. Jumlah sampel yaitu 33 pada setiap kelompok sampel dan total sampelnya 66 balita, dengan teknik pengambilan sampel yaitu purposive sampling. Analisis data menggunakan uji chi-square. Hasil penelitian menunjukkan terdapat hubungan antara kebiasaan makan dengan kejadian stunting pada anak balita di Desa Padende Kecamatan Marawola dengan $p$-value $=0,014$. Simpulan dari penelitian ini adalah terdapat hubungan antara kebiasaan makan dengan kejadian stunting pada anak balita di Desa Padende Kecamatan Marawola.
\end{abstract}

Kata kunci: kebiasaan makan, stunting, balita

\section{Pendahuluan}

Masalah gizi secara umum termasuk masalah kesehatan masyarakat. Multifaktor termasuk pemicu timbulnya masalah gizi, sehingga strategi pengendaliannya harus berhubungan dengan sejumlah sektor yang terkait (Siagian, 2010).

Masalah gizi banyak dijumpai pada masyarakat di Indonesia diantaranya kelebihan gizi, kekurangan gizi, obestitas serta stunting. Pertumbuhan anak yang 
kurang optimal termasuk efek defisiensi gizi kronis. Apabila terjadi dalam jangka waktu yang lama maka situasi ini dapat menyebabkan anak mengalami stunting (Millennium Challenge Account Indonesia, 2015).

Stunting merupakan problema dari defisiensi kebutuhan gizi dalam jangka yang panjang. Awal kejadian stunting pada saat masih dalam rahim dan akan terlihat apabila umur anak 2 tahun.

Berdasarkan pernyataan WHO mengenai standar pertumbuhan anak bahwa stunting ditentukan berdasarkan indeks tinggi badan per umur (TB/U) atau panjang badan per umur $(\mathrm{PB} / \mathrm{U})$ dengan memakai batas (z-score) $<-2$ Standar Deviasi (SD) (de Onis et al., 2013). Menurut laporan WHO bahwa prevalensi stunting pada tahun 2017 sebanyak 150,8 juta anak. Data terkini balita mengalami stunting pada tahun 2018 tercatat sebesar 22,9\% atau 154,8 juta anak.

Stunting di Asia terdapat 87 juta balita, di Amerika Latin dan di Karibia terdapat 6 juta balita serta di Afrika sebanyak 59 juta balita (World Health Organization, 2018). WHO melaksanakan penanggulangan pada permasalahan stunting baik seara nasional maupun daerah yakni sebanyak 20\%, dan di Indonesia yang tercapai sekitar 29,6\%. Berdasarkan pemantauan Status Gizi atau PSG (2017), balita yang mengalami stunting di Indonesia terdapat di 2 provinsi yaitu Bali sebesar 19,1\% dan Yogyakarta sebesar 19,8\%. Tercatat antara $30-40 \%$ kasus tertinggi yang terjadi pada provinsi lainnya (Kementerian Kesehatan Republik Indonesia,2018).

Data tahun 2018 tercatat kurang lebih $30,8 \%$ balita dengan stunting. Meskipun prevalensi tersebut lumayan tinggi, prevalensi stunting pada balita ini mulai mengalami penurunan dibanding prevalensi di tahun 2007-2013, yakni antara $36,8-37,2 \%$. Ini menandakan telah ada penanggulangan gizi anak di Indonesia (Kementerian Kesehatan Republik Indonesia, 2018).

Menurut laporan Dinas Kesehatan Provinsi Sulawesi Tengah pada tahun 2015 terdapat 443 balita stunting, pada tahun 2017 terdapat 445 balita stunting dan tahun 2018 terdapat sebanyak 522 balita stunting. Sehingga telah diketahui bahwa tiap tahunnya mulai dari tahun 2015 sampai 2018 balita stunting mengalami peningkatan (Dinas Kesehatan Provinsi Sulawesi Tengah, 2018). Selain itu, data Dinas Kesehatan Kabupaten Sigi mengenai kasus anak stunting yaitu pada tahun 2017 tercatat 1.459 kasus, tahun 2018 tercatat 2.132 kasus 
Ciptaan disebarluaskan di bawah Lisensi dan pada tahun 2019 tercatat .591 kasus (Dinas Kesehatan Kabupaten Sigi, 2019).

Balita termasuk kelompok umur yang sudah sepatutnya dijadikan perhatian penting, karena pada kelompok usia ini mudah terjadi rawan gizi. Masa balita adalah masa emas dikarenakan pada saat periode ini berlangsung, perkembangan serta pertumbuhan terjadi begitu pesat, namun masa balita pula termasuk usia dengan periode kritis.

Periode kritis berlangsung ketika balita tidak mendaptkan kebutuhan gizi yang sesuai dengan kebutuhan pertumbuhannya, yang berakibat pada terhambatnya pertumbuhan dan perkembangan pada balita. Terhambatnya pertumbuhan dan perkembangan balita dapat berlangsung ketika itu dan waktu seterusnya sampai ketika ia dewasa (Kementerian Kesehatan Republik Indonesia, 2015).

Berdasarkan hasil riset yang dilakukan oleh (Puspasari, N., \& Andriani, 2017) menyatakan ada hubungan asupan makanan dengan status gizi balita $(p=0,002$ $<0,05)$. Pemberian makan secara baik termasuk unsur terpenting yang seharusnya diberi terhadap anak yang mengandung sumber zat gizi makro seperti karbohidrat, protein dan lemak, dan mikro yakni meliputi seng dan kalsium yang semuanya berperan penting dalam tumbuh kembang anak.

Puskesmas Marawola adalah puskesmas yang terletak di Kabupaten Sigi dengan 8 wilayah kerja salah satunya Desa Padende. Balita dengan masalah stunting di Desa Padende pada tahun 2017 sampai tahun 2019 sebanyak 33 anak. (Nindyna Puspasari, 2017).

Berdasarkan hasil observasi awal didapatkan bahwa terdapat salah satu RT yang ada di Desa Padende Kecamatan Marawola mayoritas penduduknya masih awam dan dengan tingkat sosial ekonomi yang tergolong rendah, dimana kebiasaan sehari-hari mereka hanya meminta-minta atau mengharapkan bantuan dari orang lain untuk makan, sehingga anak balita mereka hanya makan makanan hasil pemberian tersebut yang berupa roti dan makanan ringan saja tanpa memperoleh nasi dan makanan bergizi yang seharusnya sangat dibutuhkan anak usia balita.

Hasil wawancara awal pada pengelola program gizi di Puskesmas Marawola bahwa sejauh ini upaya yang dilakukan dalam pencegahan stunting yaitu sosialisasi/peyuluhan secara berkala dan pemberian makanan tambahan, namun belum menyeluruh dikarenakan faktor geografis dan demografis. 
Berdasarkan masalah tersebut, maka peneliti tertarik untuk melaksanakan penelitian yang berjudul "Hubungan Kebiasaan Makan dengan Kejadian Stunting pada Anak Balita di Desa Padende Kecamatan Marawola”.

Tujuan penelitian ini adalah menganalisis kebiasaan makan dan hubungannya dengan kejadian stunting pada anak balita di Desa Padende Kecamatan Marawola

\section{Metode}

Jenis penelitian ini adalah kuantitatif dengan metode analitik dan mempergunakan rancangan case control. Penelitian dilakukan di Desa Padende Kecamatan Marawola pada tanggal 6-31 Juni tahun 2020.

Populasi dalam penelitian ini adalah semua balita di Desa Padende Kecamatan Marawola pada tahun 2019 sebanyak 139 balita. Sampel dalam penelitian ini adalah balita stunting di Desa Padende yang berjumlah 33 balita ditambah kontrol (balita tidak stunting) sebanyak 33 balita., sehingga total keseluruhan sampel yaitu sebanyak 66 balita. Teknik penentuan sampel adalah purposive sampling.

Instrumen yang digunakan adalah Food Frequency Questionnaire (FFQ) untuk variable kebiasan makan dan untuk mengukur kejadian stunting dilakukan secara langsung menggunakan indeks TB/U. Tinggi badan (TB) diukur menggunakan microtoice dengan ketelitian $0,1 \mathrm{~cm}$. Data TB yang telah diperoleh kemudian disesuaikan dengan umur dan dibandingan dengan standar antropometri $\mathrm{TB} / \mathrm{U}$ dari Buku Saku Kemenkes 2010. Analisis data menggunakan uji chi-square.

\section{Hasil}

1. Karakteristik Ibu

Tabel 1 Distribusi frekuensi ibu berdasarkan usia, pendidikan dan pendapatan di Desa

\section{Padende Kecamatan Marawola}

\begin{tabular}{|c|c|c|c|c|}
\hline \multirow{2}{*}{ Usia } & \multicolumn{2}{|c|}{ Kasus } & \multicolumn{2}{|c|}{ Kontrol } \\
\hline & $f$ & $\%$ & $f$ & $\%$ \\
\hline 19-25 tahun & 11 & 33,3 & 7 & 21,2 \\
\hline 26-35 tahun & 14 & 42,4 & 20 & 60,6 \\
\hline $36-43$ tahun & 8 & 24,3 & 6 & 18,2 \\
\hline Total & 33 & 100,0 & 33 & 100,0 \\
\hline \multirow{2}{*}{ Pendidikan } & \multicolumn{2}{|c|}{ Kasus } & \multicolumn{2}{|c|}{ Kontrol } \\
\hline & $f$ & $\%$ & $f$ & $\%$ \\
\hline Pendidikan dasar & 20 & 66,7 & 18 & 54,6 \\
\hline Pendidikan menengah & 10 & 30,3 & 11 & 33,3 \\
\hline
\end{tabular}




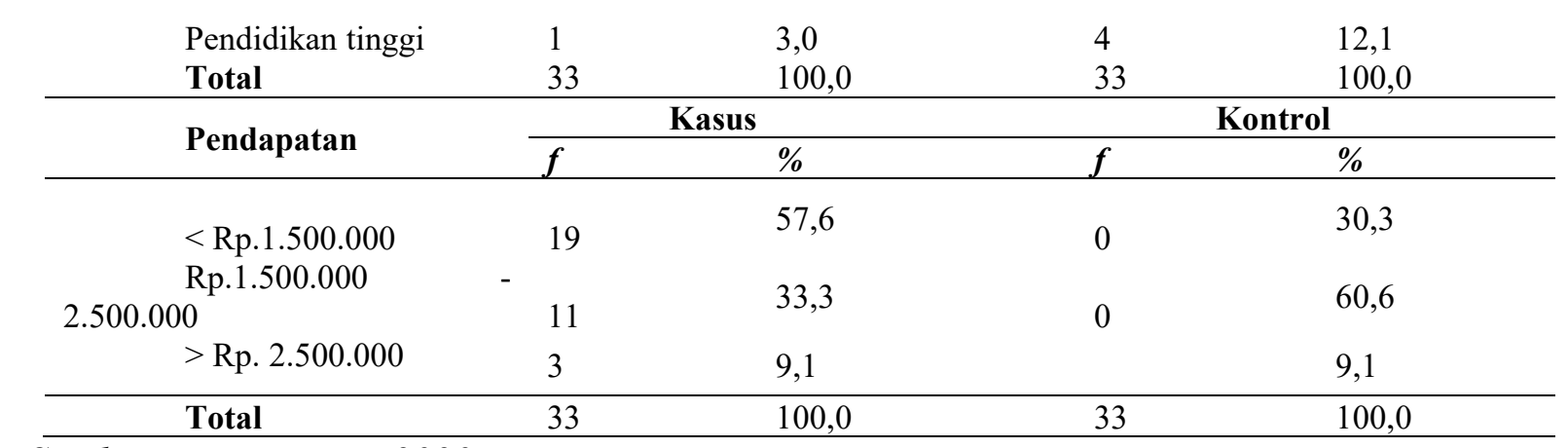

Sumber: Data Primer 2020

Tabel 1 menunjukkan bahwa dari kelompok kasus, sebagian besar ibu berusia 26-35 tahun yaitu 42,4\%. Pada kelompok kontrol, sebagian besar ibu berumur 26-35 tahun yaitu 60,6\%. Sebagian besar ibu berpendidikan dasar yaitu 66,7\%. Pada kelompok kontrol, sebagian besar ibu berpendidikan dasar yaitu $54,6 \%$ dan sebagian kecil berpendidikan tinggi yaitu 12,1\%. sebagian besar ibu memiliki pendapatan < Rp.1.500.000 yaitu 57,6\%. Pada kelompok kontrol, sebagian besar ibu. memiliki pendapatan Rp.1.500.000 2.500 .000 yaitu $60,6 \%$.

2. Karakteristik Balita

Tabel 2 Distribusi frekuensi balita berdasarkan usia, pendidikan dan pendapatan di Desa Padende Kecamatan Marawola

\begin{tabular}{|c|c|c|c|c|}
\hline \multirow{2}{*}{ Jenis Kelamin } & \multicolumn{2}{|c|}{ Kasus } & \multicolumn{2}{|c|}{ Kontrol } \\
\hline & $f$ & $\%$ & $f$ & $\%$ \\
\hline Laki-laki & 15 & 45,4 & 15 & 45,4 \\
\hline Perempuan & 18 & 54,6 & 18 & 54,6 \\
\hline Total & 33 & 100,0 & 33 & 100,0 \\
\hline \multirow{2}{*}{ Usia } & \multicolumn{2}{|c|}{ Kasus } & \multicolumn{2}{|c|}{ Kontrol } \\
\hline & $f$ & $\%$ & $f$ & $\%$ \\
\hline 2 tahun & 18 & 54,6 & 18 & 54,6 \\
\hline 3 tahun & 15 & 45,4 & 15 & 45,4 \\
\hline Total & 33 & 100,0 & 33 & 100,0 \\
\hline
\end{tabular}

Sumber: Data Primer 2020

Tabel 2 menunjukkan bahwa dari berusia 2 tahun yakni $54,6 \%$ serta sebagian kelompok kasus dan kontrol, sebagian besar kecil berusia 3 tahun yakni 45,4\%. perempuan yakni $54,6 \%$. Sebagian besar

3. Kebiasaan Makan

Tabel 3 Distribusi frekuensi anak balita berdasarkan kebiasaan makan dan kejadian stunting di Desa Padende Kecamatan Marawola 


\begin{tabular}{lccccc}
\hline \multirow{2}{*}{ Kebiasaaan makan } & \multicolumn{3}{c}{ Kasus } & \multicolumn{3}{c}{ Kontrol } \\
\cline { 2 - 5 } & $\boldsymbol{f}$ & $\boldsymbol{\%}$ & $\boldsymbol{f}$ & $\boldsymbol{\%}$ \\
\hline Jarang & 21 & 63,6 & 10 & 30,3 \\
\hline Sering & 12 & 36,4 & 23 & 69,7 \\
\hline Total & 33 & 100,0 & 33 & 100,0 \\
\hline
\end{tabular}

Sumber: Data Primer 2020

Tabel 3 menunjukkan bahwa dari kelompok kasus, sebagian besar anak balita mempunyai kebiasaan makan yang jarang yaitu $63,6 \%$ dan sebagian kecil anak balita mempunyai kebiasaan makan yang sering yaitu 36,4\%. Pada kelompok kontrol, sebagian besar anak balita mempunyai kebiasaan makan yang sering yaitu 69,7\% dan sebagian kecil anak balita mempunyai kebiasaan makan yang jarang yaitu 30,3\%. Anak yang stunting yaitu $50 \%$ dan anak yang tidak stunting yaitu $50 \%$.

4. Hubungan Kebiasaan Makan dengan Kejadian Stunting

Tabel 4 Hubungan antara kebiasaan makan dengan kejadian stunting pada anak balita di Desa Padende Kecamatan Marawola

\begin{tabular}{|c|c|c|c|c|c|c|}
\hline \multirow{3}{*}{ Kebiasaan makan } & \multicolumn{4}{|c|}{ Kejadian stunting } & \multirow[t]{3}{*}{$P$-value } & \multirow{3}{*}{$\begin{array}{l}\text { OR } \\
(\mathrm{CI}) \\
\end{array}$} \\
\hline & \multicolumn{2}{|c|}{ Stunting (kasus) } & \multicolumn{2}{|c|}{$\begin{array}{l}\text { Tidak stunting } \\
\text { (kontrol) }\end{array}$} & & \\
\hline & $\mathbf{n}$ & $\%$ & $\mathbf{n}$ & $\%$ & & \\
\hline Jarang & 21 & 7,7 & 0 & 32,3 & & 4,025 \\
\hline Sering & 12 & 4,3 & 3 & 65,7 & 0,014 & $(1,442-$ \\
\hline Total & 33 & 0,0 & 3 & 50,0 & & $11,238)$ \\
\hline
\end{tabular}

Sumber: Data Primer 2020

Tabel 4 menunjukkan bahwa dari 31 anak balita yang mempunyai kebiasaan makan yang jarang terhadap sumber karbohidrat, protein, serat, terdapat 21 anak balita $(67,7 \%)$ yang stunting dan 10 anak balita (32,3\%) yang tidak stunting, sedangkan dari 35 anak balita yang mempunyai kebiasaan makan yang sering terhadap sumber karbohidrat, protein, serat, terdapat 12 anak balita (34,3\%) yang stunting dan 23 anak balita (65,7\%) yang tidak stunting.

Hasil uji statistik menggunakan chisquare diperoleh $p$-value $=0,014$ ( $p$-value $\leq$ $0,05)$ yang artinya ada hubungan antara kebiasaan makan dengan kejadian stunting pada anak balita di Desa Padende Kecamatan Marawola. Nilai Odds Ratio (OR) yaitu 4,025 artinya anak balita yang mempunyai kebiasaan makan yang jarang terhadap sumber karbohidrat, protein, serat, 
Ciptaan disebarluaskan di bawah Lisensi memiliki risiko atau peluang 4 kali lebih besar untuk mengalami stunting dibanding anak balita yang mempunyai kebiasaan makan yang sering terhadap sumber karbohidrat, protein, serat.

\section{Pembahasan}

1. Kebiasaan makan pada anak balita di Desa Padende Kecamatan Marawola

Hasil penelitian menunjukkan bahwa dari 66 balita (kasus dan kontrol) dalam penelitian ini, sebagian besar anak balita mempunyai kebiasaan makan yang sering terhadap sumber karbohidrat, protein, serat yaitu 53\%, dan sebagian kecil anak balita mempunyai kebiasaan makan yang jarang terhadap sumber karbohidrat, protein, serat yaitu $47 \%$.

\section{Sebagian besar anak balita} mempunyai kebiasaan makan yang sering terhadap sumber karbohidrat, protein, serat dikarenakan orang tua/ibu mempunyai pengetahuan yang sudah baik tentang gizi, sehingga ibu akan mengupayakan anaknya untuk memperoleh makanan yang bergizi demi kesehatan anak balitanya. Sementara pada anak balita yang mempunyai kebiasaan makan yang jarang terhadap sumber karbohidrat, protein, serat dikarenakan pendapatan orang tua/ibu yang rendah, sehingga ibu tidak dapat menyediakan makanan dengan gizi yang baik untuk anak balitanya.

Kurangnya pengetahuan ibu tentang gizi menjadi satu dari berbagai faktor yang berpengaruh terhadap gizi balita. Diperlukan pengetahuan yang baik mengenai gizi untuk dapat menyusun menu makanan bergizi agar anak tidak kekurangan gizi (Febry \& Marendra, 2013)

Pengetahuan ibu terhadap gizi amatlah penting, karena umumnya ibu dengan pengetahuan yang baik terhadap gizi akan menyediakan makanan yang bergizi bagi keluarganya dibanding ibu dengan pengetahuan yang kurang (Khoirun \& Nadhiroh, 2015)

2. Kejadian stunting pada anak balita di Desa Padende Kecamatan Marawola

Hasil penelitian menunjukkan bahwa dari 66 anak balita dalam penelitian ini, jumlah balita stunting yaitu 50\% dan balita tidak stunting yaitu 50\%. Menurut asumsi peneliti, anak balita yang mengalami stunting disebabkan oleh faktor pengetahuan orang tua yang kurang baik dan rendahnya pendapatan sehingga anak balita tidak mendapatkan asupan makanan yang bergizi, yang pada akhirnya menjadikan anak balita mudah mengalmi stunting. Selain itu dapat dikarenakan orang tua yang sibuk bekerja, 
sehingga kurangnya waktu orang tua dalam mengontrol makanan yang dikonsumsi oleh anaknya. Berbeda halnya pada anak balita yang tidak stunting dapat dikarenakan pengetahuan orang tua yang sudah baik dan pendapatan yang mencukupi dalam penyediaan makanan bergizi sehingga anak balita mempunyai status gizi yang baik.

Hasil penelitian Julia \& Amin, (2015) yaitu terdapat hubungan antara pendapatan keluarga dengan kejadian stunting. Hal ini disebabkan tidak mampunya keluarga dalam menyediakan bahan makanan dengan kandungan gizi yang menyebabkan mempengaruhi status gizi keluarga terutama pada anak balita.

3. Hubungan antara kebiasaan makan dengan kejadian stunting pada anak balita di Desa Padende Kecamatan Marawola

Hasil penelitian bahwa terdapat hubungan antara kebiasaan makan dengan kejadian stunting pada anak balita di Desa Padende Kecamatan Marawola dengan pvalue $=0,014(p$-value $\leq 0,05)$. Nilai Odds Ratio $(\mathrm{OR})=4,025$ artinya yaitu anak balita yang mempunyai kebiasaan makan yang jarang terhadap sumber karbohidrat, protein, serat, memiliki risiko atau peluang 4 kali lebih besar untuk mengalami stunting dibanding anak balita yang mempunyai kebiasaan makan yang sering terhadap sumber karbohidrat, protein, serat.

Adanya hubungan kebiasaan makan dengan kejadian stunting pada anak balita di Desa Padende Kecamatan Marawola dikarenakan anak balita yang sering (> 3x/minggu) mengonsumsi makanan dari sumber karbohidrat, protein dan serat akan membuat gizinya terpenuhi, sebab diusia balita membutuhkan makanan yang kaya akan karbohidrat, protein dan serat untuk proses pertumbuhan dan perkembangan. Anak balita yang jarang ( $\leq 3 \mathrm{x} /$ minggu) mengonsumsi makanan dari sumber karbohidrat seperti nasi, protein seperti ikan segar dan serat seperti sayur kelor akan menyebabkan anak kekurangan gizi yang pada akhirnya akan menghambat tumbuh kembang mereka atau dengan kata lain mereka akan mudah mengalami masalah gizi seperti stunting.

Anak balita yang tidak stunting (kontrol) tetapi mempunyai kebiasaan makan yang jarang pada makanan dari sumber karbohidrat, protein dan serat dikarenakan berdasarkan wawancara kesehatan yang peneliti lakukan pada ibu balita saat penelitian menunjukkan bahwa anak balitanya ketika lahir memiliki berat badan normal, mendapatkan ASI secara eksklusif, tidak memiliki riwayat penyakit 
infeksi, mempunyai orang tua dengan tinggi badan yang normal, dan ibu yang mengupayakan mengonsumsi makanan bergizi saat anak balita tersebut masih berada di kandungan. Hal ini yang bisa saja menjadi faktor anak balita tersebut tidak stunting (kontrol) walaupun mempunyai kebiasaan makan yang jarang. Sedangkan pada anak balita yang stunting (kasus) tetapi mempunyai kebiasaan makan yang sering pada makanan dari sumber karbohidrat, protein dan serat dikarenakan berdasarkan wawancara kesehatan yang peneliti lakukan pada ibu balita saat penelitian menunjukkan bahwa balita tidak memperoleh ASI secara eksklusif, adanya orang tua yang memiliki tinggi badan tidak normal (pendek), dan anak balita yang memiliki riwayat penyakit infeksi seperti cacingan dan ISPA, sehingga walaupun kebiasaan makan anak balita sudah baik atau sering mengkonsumsi makanan bergizi, tetapi jika memiliki faktor risiko lain maka anak balitapun akan memiliki risiko yang tinggi untuk mengalami stunting.

Penemuan berbagai fakta oleh peneliti bahwa dari sebagian ibu balita tentang kebiasaan makan anak balita stunting, dimana anak balita sejak usianya masih di bawah 6 bulan ibunya sudah membiasakan anak balita untuk mengonsumsi roti dan buah pisang. Anak balita pun jarang diberikan nasi dan makanan bergizi lainnya karena faktor pendapatan orang tua yang tidak mencukupi dan memaksakan mereka menjadi pemintaminta/pengemis di sekitaran jalan Kota Palu terutama di lampu merah dan mereka juga turut membawa anak balitanya untuk meminta-minta bantuan pada orang yang ditemui, yang menyebabkan anak rentan terhadap penularan penyakit infeksi seperti ISPA karena asap kendaraan, selain itu menyebabkan kebiasaan makan anak menjadi tidak baik sebab ibu tidak dapat menyediakan makanan dengan gizi tinggi.

Pada umumnya anak balita membutuhkan makanan bergizi seperti makanan yang mengandung karbohidrat, protein dan serta yang mencukupi untuk proses tumbuh kembang dan kelangsungan hidup anak. Sehingga jika anak tidak mendapatkan asupan gizi yang memenuhi, maka anak akan mudah mengalami kekurang4 gizi yang dapat mengganggu proses tumbuh kembangnya bahkan dapat berakhir dengan kematian pada anak (Sulistyoningsih, 2012).

Jenis makanan yang dikonsumsi dapat pula menentukan status gizi pada anak. Ini terjadi sebab balita adalah usia rawan gizi yang menyebabkan pemberian jenis 
makanan mesti selaras dengan apa yang dibutuhkan oleh tubuh serta daya cerna anak. Kevariatifan jenis makanan serta kecukupan nilai gizinya mialnya makanan yang mengandung karbohidrat, protein dan serta amatlah perlu dalam mencegah gizi kurang pada anak. Anak yang terbiasa makan baik mesti dibiasakan saat dini melalui langkahlangkah pemberian makanan yang bermacam-macam serta informasi sebaiknya diberikan pada anak balita waktu makan yang tepat. Sehingga dari hal ini anak dapat membiasakan diri dengan pola makan yang sehat yang pada akhirnuya dapat menjadikan dirinya tercegah dari permasalahan kependekan (Sutomo \& Anggraini, 2013).

Jenis dan bahan makanan yang diatur sedemikian mungkin dan dimakan mesti pengaturannya harus cara yang tepat sehingga anak tidak mudah jenuh dengan jenis makanan tertentu. Makanan yang terpenuhi gizi seimbang yakni bila anak balita makan dari makanan yang mengandung sumber zat tenaga, zat pembangun, zat pengatur. Balita yang mendapatkan makan dengan gizi seimbang akan sulit mengalami stunting (Sutomo \& Anggraini, 2013).

Banyak fakor yang menyebabkan anak mudah mengalami stunting, diantaranya ibu yang kekurangan gizi ketika anak masih di kandungan, anak yang tidak diberikan ASI eksklusif, anak dengan pola makan yang tidak baik, anak memiliki riwayat penyakit infeksi, pengetahuan ibu yang kurang, pendapatan yang tidak mencukupi kebutuhan rumah tangga, dll (Waryono, 2012).

Kondisi gizi anak disebabkan adanya cara asuhan dari orang tua sebab anak masih bergantung pada pemenuhan asupan makan serta perawatan kesehatannya. Bukan hanya itu, makanan yang berkualitas serta bergizi amatlah bergantung pada pola asuh makan anak yang dilakukan dari keluarga. Kebanyakan orang tua yang berpenghasilan rendah tidak dapat menyediakan makanan yang bergizi tinggi untuk anaknya sehingga anak memiliki risiko tinggi mengalami stunting (Martianto, D., \& Ariani, 2010).

Hasil penelitian ini sejalan dengan hasil penelitian yang dilakukan oleh (Prakhasita, 2018) di wilayah kerja Puskesmas Tambak Wedi Surabaya bahwa pola pemberian makan ada hubungannya dengan kejadian stunting pada balita usia 1259 bulan dengan nilai $\mathrm{p}=0,002$. Pola pemberian yang tepat merupakan pola pemberian makan yang sesuai dengan jenis makanan, jumlah makanan dan jadwal makan anak. Anak dengan pola pemberian makanan yang tepat, sebagian besar tidak 
JURNAL ILMU KESEHATAN BHAKTI HUSADA:

HeALth SCIENCES JoURNAL, Vol. 12 No. 01, Juni 2021

DOI: $10.34305 / J I K B H . V 12 \mathrm{I} 1.252$
Ciptaan disebarluaskan di bawah Lisensi mengalami stunting (Febry \& Marendra, 2013)

Trisnawati (2018) menyatakan bahwa asupan energi balita adalah sebagian besar kurang. Ada banyak balita yang mempunyai kategori asupan kurang sebab anak tidak teratur makannya, terutama untuk konsumsi nasi yang menyebabkan balita rentang terhadap terjadinya stunting.

\section{Kesimpulan}

Simpulan berdasarkan hasil penelitian yaitu: sebagian besar anak balita di Desa Padende Kecamatan Marawola mempunyai kebiasaan makan yang sering terhadap sumber karbohidrat, protein dan serat; ada hubungan antara kebiasaan makan dengan kejadian stunting pada anak balita di Desa Padende Kecamatan Marawola.

\section{Saran}

Diharapkan pihak Puskesmas Marawola dapat melakukan upaya penanggulangan kejadian stunting pada balita dengan melakukan kerja sama dengan aparat desa setempat dan mengadakan penyuluhan secara aktif serta kunjungan ke rumah-rumah balita yang orang tuanya berpenghasilan rendah $(<\mathrm{Rp} .1 .500 .000)$ untuk memberikan sosialisasi dan makanan tambahan pada balita. Selain itu diharapkan agar ibu balita untuk memperhatikan kualitas dan kuantitas makanan yang akan diberikan pada anaknya sehingga dapat mencegah masalah serius yang diakibatkan karena kurangnya kandungan gizi pada makanan.

\section{Daftar Pustaka}

de Onis, M., Dewey, K., \& Borghi, E. (2013). The World Health Organization's global target for reducing childhood stunting by 2025 : rationale and proposed actions. Maternal \& Child Nutrition, 9(Suppl 2), 6-26.

Dinas Kesehatan Kabupaten Sigi. (2019). Profil Dinas Kesehatan Kabupaten Sigi. Sigi : Dinkes Kabupaten Sigi.

Dinas Kesehatan Provinsi Sulawesi Tengah. (2018). Profil Kesehatan Provinsi Sulawesi Tengah Tahun 2018. Palu : Dinkes Provinsi Sulawesi Tengah.

Febry, A., \& Marendra, Z. (2013). Buku Pintar Menu Balita. Jakarta : Wahyu Media.

Julia, M., \& Amin, N. (2015). Faktor sosiodemografi dan tinggi badan orang tua serta hubungannya dengan kejadian stunting pada balita. Jurnal Gizi dan Dietetik Indonesia, 2(3), 1-6.

Kementerian Kesehatan Republik Indonesia. (2018a). Buku Saku Pemantauan Status Gizi Tahun 2017. Kemenkes RI.

Kementerian Kesehatan Republik Indonesia. (2018b). Laporan Nasional Riskesdas 2018. 
JURNAL ILMU KESEHATAN BHAKTI HUSADA:

HeALth SCIENCES JoURNAL, Vol. 12 No. 01, Juni 2021

DOI: $10.34305 /$ JIKBH.V12I1.252
Ciptaan disebarluaskan di bawah Lisensi

Wedi Surabaya. Universitas Airlangga

Kementerian Kesehatan Republik Indonesia. (2015). Pedoman Penyelenggaraan Pelatihan Konseling Menyusui Dan Pelatihan Fasilitator Konseling Menyusui. Jakarta : Kemenkes RI.

Khoirun, N., \& Nadhiroh, S. (2015). Faktor yang berhubungan dengan kejadian stunting pada balita. Jurnal Media Gizi Indonesia, 10(1), 1-10.

Martianto, D., \& Ariani, M. (2010). Analisis Perubahan Konsumsi dan Pola Konsumsi Pangan Masyarakat dalam Dekade Terakhir. Jakarta : Widya Karya Nasional Pangan dan Gizi.

Millennium Challenge Account Indonesia. (2015). Backgrounder: stunting dan masa depan indonesia.

Nindyna Puspasari, \& M. A. (2017). Hubungan Pengetahuan Ibu tentang Gizi dan Asupan Makan Balita dengan Status Gizi Balita (BB/U) Usia 12-24 Bulan. Amerta Nutrition, 1(4), 369378.

https://doi.org/10.20473/amnt.v1.i4.20 17.369-378

Prakhasita, R. (2018). Hubungan pola pemberian makan dengan kejadian stunting pada balita usia 12-59 bulan di wilayah kerja puskesmas Tambak
Puspasari, N., \& Andriani, M. (2017). Hubungan asupan makanan dengan status gizi balita di wilayah kerja Puskesmas Tambak Kota Surabaya. Amerta Nutrition, 1(4), 369-378.

Siagian, A. (2010). Epidemiologi Gizi. Jakarta : Erlangga.

Sulistyoningsih, H. (2012). Gizi untuk Kesehatan Ibu dan Anak. Yogyakarta : Graha Ilmu.

Sutomo, B., \& Anggraini, D. (2013). Menu Sehat Alami untuk Batita dan Balita. Jakarta : PT. Agromedia Pustaka.

Trisnawati, M. (2018). Faktor-Faktor Yang Berhubungan Dengan Kejadian Stunting Pada Balita Usia 24-59 Bulan Di Desa Kidang Kecamatan Praya Timur Kabupaten Lombok Tengah. Sekolah Tinggi Kesehatan Ngudi Waluyo Ungaran.

Waryono. (2012). Pemberian Makanan, Suplemen dan Obat pada Anak. Jakarta : EGC

World Health Organization. (2018). In Exclusive Breastfeeding For Optimal Growth, Development, And Health Of Infan. WHO Press. 